CZASOPISMO INŻYNIERII LĄDOWEJ, ŚRODOWISKA I ARCHITEKTURY JOURNAL OF CIVIL ENGINEERING, ENVIRONMENT AND ARCHITECTURE

JCEEA, t. XXXIV, z. 64 (3/I/17), lipiec-wrzesień 2017, s. 281-291, DOI: 10.7862/rb.2017.122

\author{
Wojciech MAZUR ${ }^{1}$ \\ Radosław JASIŃSKI ${ }^{2}$ \\ Łukasz DROBIEC ${ }^{3}$
}

\title{
NOŚNOŚĆ STREF PRZYPODPOROWYCH NADPROŻY Z AUTOKLAWIZOWANEGO BETONU KOMÓRKOWEGO
}

\begin{abstract}
W artykule przedstawiono wyniki badań doświadczalnych oraz obliczenia weryfikujące nośność stref przypodporowych prefabrykowanych nadproży z autoklawizowanego betonu komórkowego. Zbadano trzy serie elementów zróżnicowanych pod względem wymiarów poprzecznych oraz typu zbrojenia. Wykazano istotny wpływ sposobu zakotwienia podłużnych prętów na sposób zarysowania i zniszczenia oraz nośność belek.
\end{abstract}

Słowa kluczowe: beton komórkowy, nadproża prefabrykowane, nośność na ścinanie, zakotwienie

\section{Wstęp, cel pracy}

Nadproża to belki przekrywające otwory okienne i drzwiowe. Zazwyczaj wykonuje się je z kształtowników stalowych, jako żelbetowe elementy wykonywane na miejscu budowy lub prefabrykowane albo w postaci prefabrykowanych rozwiązań systemowych. Docelowo nadproża współpracują z murem, jednak w fazie montażowej najczęściej pracują jako belki swobodnie podparte i mogą być obciążone siłami skupionymi. Konieczne jest więc sprawdzenie nośności na zginanie i ścinanie w tej fazie pracy. Zagadnienia związane z nośnością elementów stalowych i żelbetowych są dość dobrze rozeznane. Prefabrykowane nadproża muszą spełniać wymogi normy [1] dotyczącej specyfikacji wyrobów dodatkowych do murów, a nośność określana jest na podstawienie obliczeń oraz badań według norm $[2,3,4]$.

Kształt zbrojenia zdeterminowany procesem produkcji, właściwości mechaniczne betonu komórkowego oraz konieczność zastosowania środków

\footnotetext{
${ }^{1}$ Autor do korespondencji / corresponding author: Wojciech Mazur, Wydział Budownictwa, Politechnika Śląska, +48 3223711 27, wojciech.mazur@polsl.pl

2 Radosław Jasiński, Wydział Budownictwa, Politechnika Śląska

${ }^{3}$ Łukasz Drobiec, Wydział Budownictwa, Politechnika Śląska
} 
ochronny antykorozyjnej sprawiają, że określenie nośności elementów $\mathrm{z}$ betonu komórkowego są bardziej złożone niż w przypadku elementów żelbetowych. $\mathrm{W}$ artykule przedstawiono mechanizm zniszczenia belek nadprożowych i porównawczych obliczeń nośności stref podporowych określonych na podstawie zaleceń normy [4], EC-2 [5] oraz [6]. Wykonano obliczenia sprawdzające, których celem było sformułowanie wstępnych wniosków dotyczących procedur sprawdzania nośności na ścinanie.

\section{Modele badawcze, stanowisko badawcze, procedura badań}

Badania doświadczalne obejmowały trzy serie elementów zróżnicowanych pod względem geometrii, wytrzymałości betonu, struktury zbrojenia poprzecznego i podłużnego, gatunku stali. Elementy serii A i C miały przekrój poprzeczny $176 \times 240 \mathrm{~mm}$ i długość całkowitą równą $2000 \mathrm{~mm}$. Element serii D różnił się pod względem wymiarów przekroju poprzecznego, które wynosiły $200 \times 249 \mathrm{~mm}$.

a)
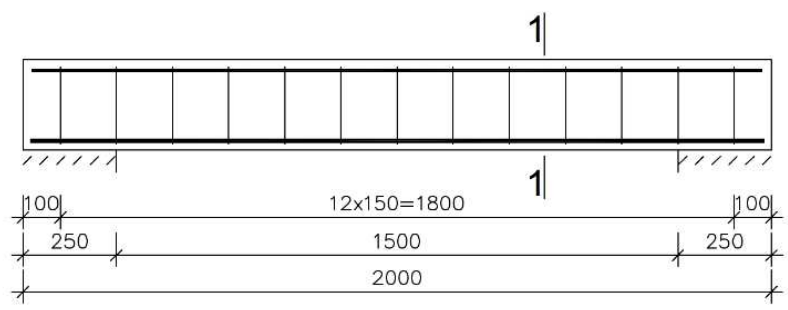

1

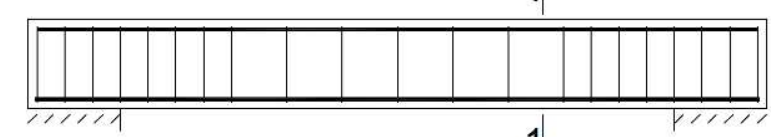

b)

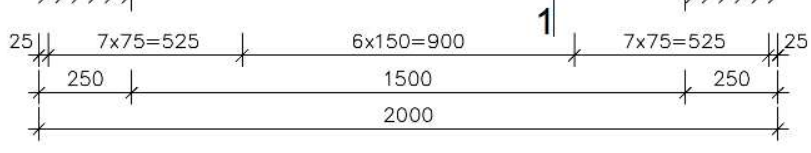

c)

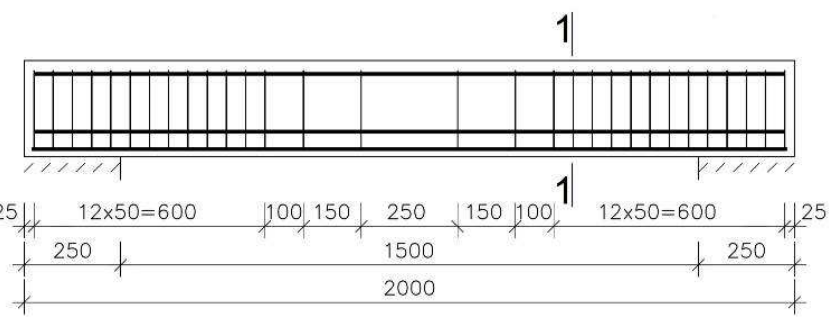

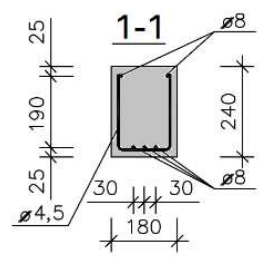
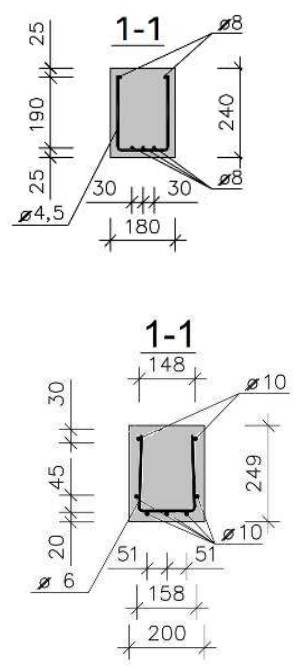

Rys. 1. Zbrojenie nadproży: a) seria A, b) seria C, c) seria D

Fig. 1. View of reinforcement of lintels: a) serie A, b) serie C, c) serie D 
Wszystkie modele podparto symetrycznie za pomocą dwóch podpór (przegubowo przesuwnej i przegubowo nieprzesuwnej) w rozstawie osiowym wynoszącym $1666 \mathrm{~mm}$ (według normy [4] $l-2 \times \mathrm{a}_{0} \times 2 / 3$, gdzie a 0 stanowi długość oparcia na murze). Zbrojenie nadproży stanowiły pręty połączone poprzez zgrzewanie i następnie odpowiednio wygięte. Wszystkie pręty w elementach serii A i C wykonano jako żebrowane. Zbrojenie podłużne stanowiły pręty o średnicy $\phi 8 \mathrm{~mm}$ (dwa w strefie ściskanej i trzy w strefie rozciąganej), a zbrojenie poprzeczne pręty średnicy $\phi 4,5 \mathrm{~mm}$. Rozstaw strzemion w nadprożach serii A był stały na całej długości elementu i wynosił $150 \mathrm{~mm}$ (rys. 1a). W przypadku nadproży serii $\mathrm{C} w$ strefie przypodporowej rozstaw strzemion został zmniejszony o połowę i wynosił $75 \mathrm{~mm}$ (rys. 1b). W elemencie serii D zbrojenie podłużne stanowiły gładkie pręty o średnicy $\phi 10 \mathrm{~mm}(2 \mathrm{w}$ strefie ściskanej i $5 \mathrm{w}$ strefie rozciąganej), a zbrojenie poprzeczne stanowiły pręty średnicy $\phi 6 \mathrm{~mm}$ także bez żebrowania. Rozstaw strzemion w strefie przypodporowej wynosił $50 \mathrm{~mm}$ i wzrastał do wartości $250 \mathrm{~mm}$ w środkowej strefie elementu (rys. 1c). Zbrojenie nadproży we wszystkich modelach zostało zabezpieczone antykorozyjnie, w postaci powłoki mineralnej (nadproża serii A i C) lub syntetycznej z tworzywa sztucznego (nadproża serii D). Długości zakotwienia prętów zbrojenia podłużnego za osią podpór wynosiły $21,5 \phi \mathrm{w}$ belkach serii A, C oraz $17 \phi \mathrm{w}$ belkach serii D, a więc mniej niż zalecenia producenta oraz wymogi normy EC-2 [5], wg których $l_{\mathrm{b}, \min }=31 \phi$ (serie A i C) $-27 \phi($ seria D).

Do realizacji badań zaprojektowano i wykonano stanowisko badawcze, którego ulegało niewielkim modyfikacjom zależnie od wymiaru belek. Schemat stanowiska oraz jego widok z modelem badawczym pokazano na rys. 2. Nadproża układano na podporach współosiowo ze stalową ramą. Obciążenie wywoływane siłownikiem hydraulicznym przykładano na belkę przez stalowy trawers i rejestrowano poziom obciążenia $\mathrm{F}$ za pośrednictwem siłomierza. Trawers rozdzielał obciążenie na parę sił skupionych przyłożonych w jednej czwartej odległości między osiami podpór.

a)

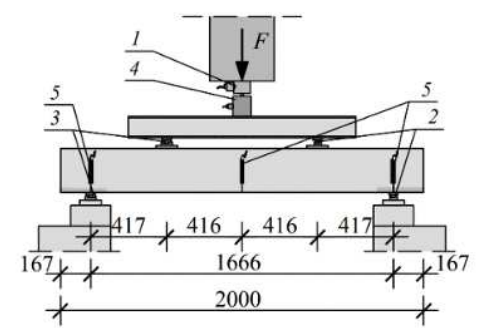

b)

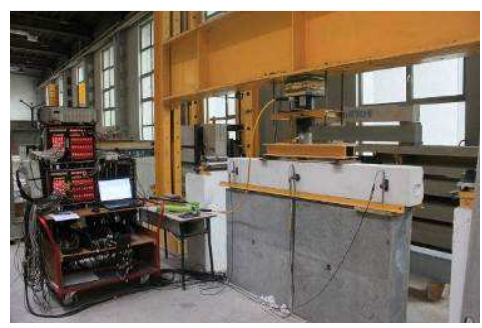

Rys. 2. Stanowisko badawcze: a) schemat; 1 - siłownik hydrauliczny, 2 - podpora nieprzesuwna, 3 - podpora przesuwna, 4 - siłomierz, 5 - indukcyjny przetwornik przemieszczeń, b) widok

Fig. 2. Test stand: a) shame; 1 - hydraulic jack, 2 - fixed support, 3 - free support, 4 - force gauge, 5 - displacement induction gauge, b) overall view 
Belki obciążano monotonicznie, stopniując przyrost siły co $5 \mathrm{kN}$ w celu rejestracji rys. W trakcie badań dokonywano za pośrednictwem automatycznego stanowiska pomiarowego (ASP) pomiaru oraz rejestracji siły z siłomierza i ugięcia. Prowadzono również kontrolę zarysowania elementów.

\section{Materiały}

Próbki do badań materiałowych elementu serii A, C i D pobrano po zbadaniu nadproża z nieuszkodzonych fragmentów strefy przypodporowej. Szczegółowe badania materiałowe elementów serii A i C przedstawiono w pracy [8]. Badania wytrzymałości na ściskanie betonu komórkowego przeprowadzono według normy [9] na trzech kostkach $(100 \times 100 \times 100 \mathrm{~mm})$ i wyniosła odpowiednio $\mathrm{f}_{\mathrm{c}}=4,19 \mathrm{MPa}$, $(v=32,2 \%)$ w elementach serii A i C oraz $\mathrm{f}_{\mathrm{c}}=4,75 \mathrm{MPa},(v=11,4 \%)$ w elemencie serii D. Badanie prętów zbrojenia podłużnego przeprowadzono zgodnie z normą [10]. W belkach serii A i C uzyskano $R_{m} / R_{p 0,2}=612 / 566=1,08=f_{t k} / f_{y k}=1,08$, a w elemencie serii $D$ uzyskano $R_{m} / R_{p 0,2}=575,3 / 535,7=1,07<f_{t k} / f_{y k}=1,08$, co pozwoliło zaklasyfikować stal do klasy B wg EC-2 [5]. Niewielka długość prętów zbrojenia poprzecznego $(<300 \mathrm{~mm})$ wykluczała wykonanie badań wytrzymałościowych, dlatego w dalszych analizach przyjmowano parametry dla stali zbrojenia podłużnego (identyczne użebrowanie lub brak użebrowania).

\section{Wyniki i analiza}

Mechanizm zarysowania belek serii A i C był taki sam. W pierwszej kolejności powstały zarysowania giętne (rys. 3a), które powstawały w przęśle i rozwijały się mniej więcej do 3/4 wysokości elementu. Wzrost obciążenia powodował powstanie ukośnych rys $\mathrm{w}$ strefie ścinania rys. 3b biegnących niemal przez całą wysokość belki. Dalszy wzrost obciążenia spowodował wystąpienie ukośnych rys w dolnej strefie belki rys. 3c, które przed zniszczeniem połączyły się z powstałymi dość gwałtownie poziomymi rysami w poziomie zbrojenia podłużnego - rys. 3d.

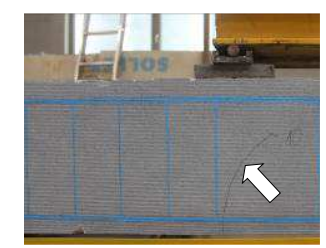

a)

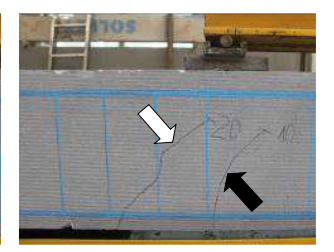

b)

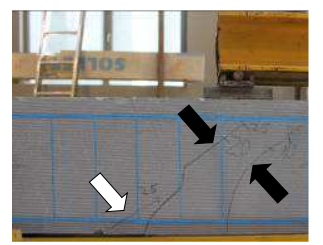

c)

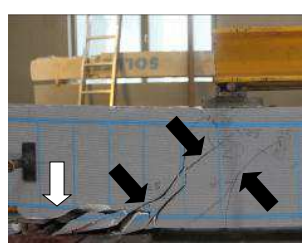

d)

Rys. 3. Propagacja rys w nadprożu C2 w kroku obciążenia: a) 2, b) 4, c) 5, d) 6

Fig. 3. Propagation of lintel C2 at load step: a) 2, b) 4, c) 5, d) 6 


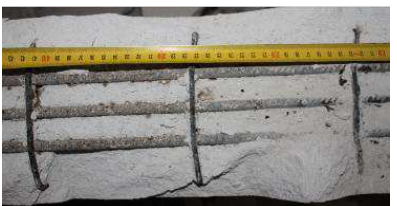

a)

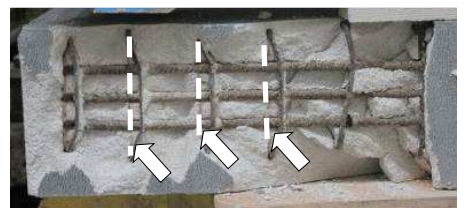

b)

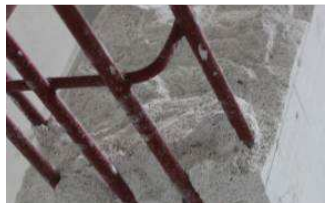

c)

Rys. 4. Zakotwienie zbrojenia po badaniach: a) seria A, b) seria C, c) seria D

Fig. 4. Bars anchorage after test: a) serie A, b) serie C, c) serie D

Każdorazowo, zniszczenie wystąpiło przy jednej z podpór, gdzie oprócz rys ukośnych powstały także rysy w poziomie dolnego zbrojenia podłużnego, wynikające $\mathrm{z}$ utraty zakotwienia prętów. $\mathrm{W}$ belce serii $\mathrm{D}$ pręty podłużne nie utraciły zakotwienia, ale podobnie jak w belkach serii A i C zniszczenie wystąpiło w strefie przypodporowej. W strefach zakotwienia prętów belek serii A i C wystąpiło uszkodzenie poprzecznych prętów (strzemion) połączonych z prętami podłużnymi - rys. 4a, rys. 4b (wygięcie zaznaczone linią przerywaną na rys. $4 \mathrm{~b}$ ). $\mathrm{Z}$ kolei w belkach serii $\mathrm{D}$ po badaniach odsłonięte zbrojenie nie wykazało żadnych uszkodzeń (rys. 4c). Na rysunkach 5-7 przedstawiono obrazy zarysowania wszystkich badanych belek.

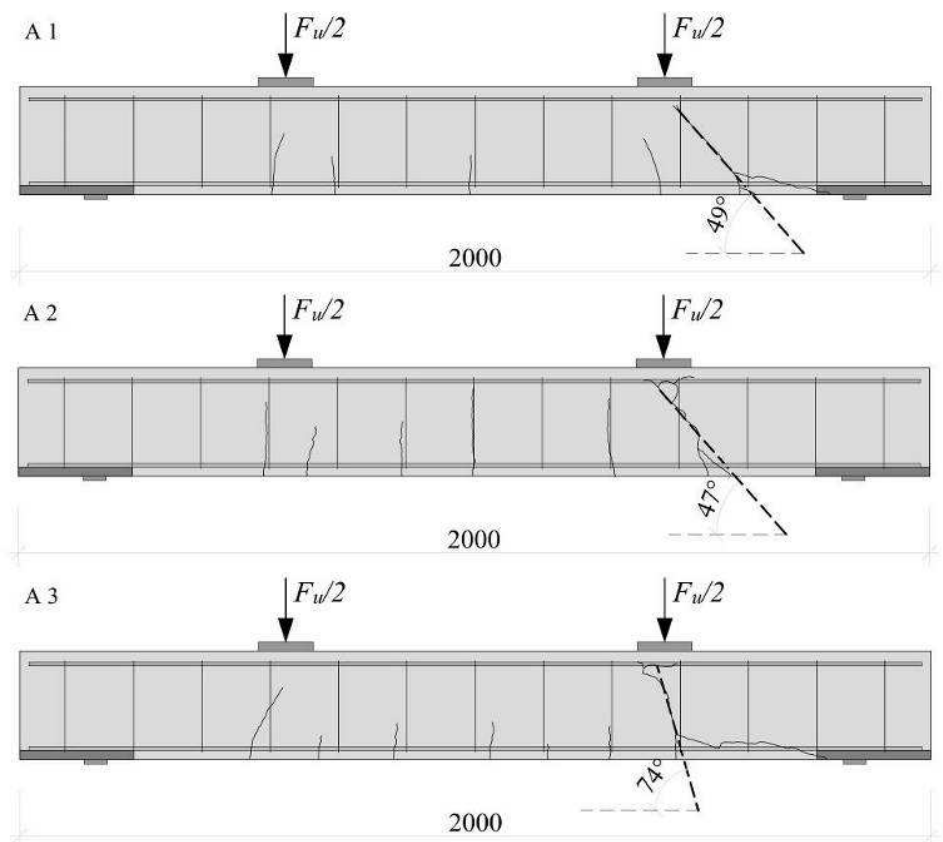

Rys. 5. Widok zarysowania belek serii A

Fig. 5. Cracking patterns of beams series A 

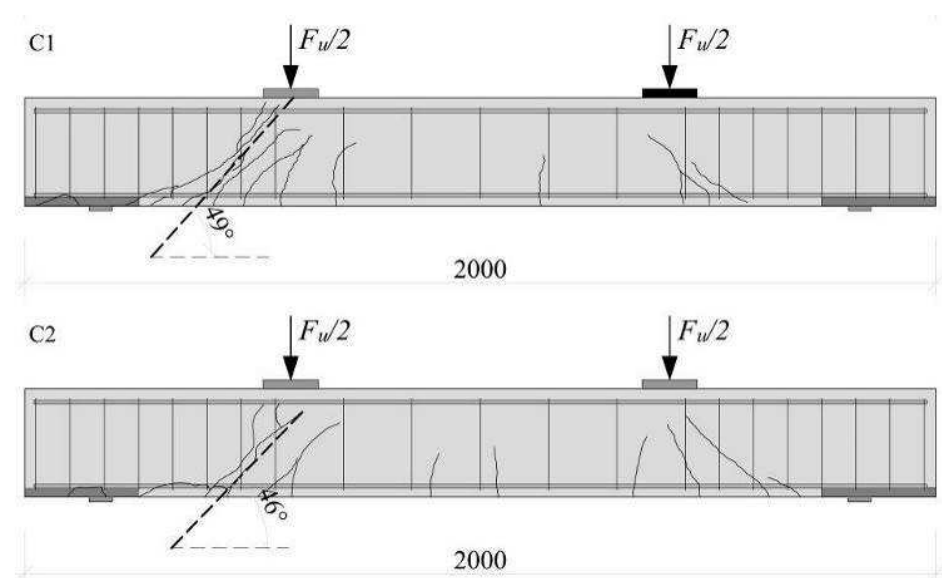

Rys. 6. Widok zarysowania belek serii $\mathrm{C}$

Fig. 6. Cracking patterns of beams series $\mathrm{C}$

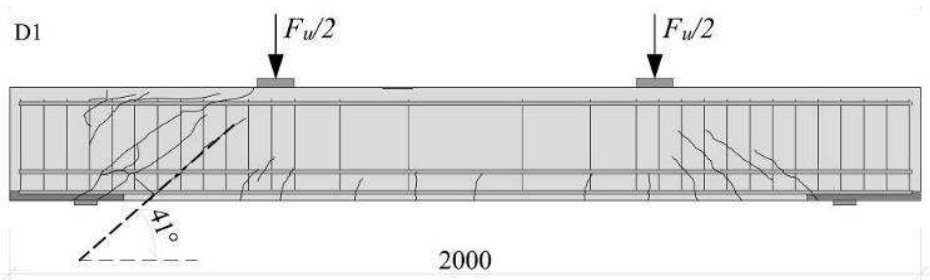

Rys. 7. Widok zarysowania belki serii D

Fig. 7. Cracking patterns of beam series D

Na podstawie obrazów zarysowań odcinków podporowych określono kąty nachylenia ściskanych krzyżulców betonowych $\Theta_{\text {test }}=41^{\circ} \div 74^{\circ}$ (powstałe przed utratą nośności zakotwienia) i obliczono odpowiadające im wartości $\operatorname{ctg}\left(\Theta_{\text {test }}\right)=0,29 \div 1,15$. Uwzględniając parametry wytrzymałościowe materiałów nadproży obliczono także wartości $\operatorname{ctg}\left(\Theta_{\text {cal }}\right)$ z zależności (1) wg [7]. Do analizy elementów serii $\mathrm{C}$ i $\mathrm{D}$ dopuszczono $\operatorname{ctg}\left(\Theta_{\text {cal }}\right)=0,85$ mniejszy niż zalecana wg [5] wartość z przedziału zapisanego w postaci (2).

$$
\begin{aligned}
& \operatorname{ctg} \Theta_{c a l}=\sqrt{\frac{f_{c k} V}{\rho_{w} R_{m}}-1} \\
& 1,0 \leq \operatorname{ctg} \Theta_{c a l} \leq 2,0
\end{aligned}
$$

Obliczeniowe nośności na ścinanie odcinków przypodporowych $V_{R}$ wyznaczono na podstawie normy EC-2 [5] oraz normy przeznaczonej do obliczeń prefabrykowanych elementów zbrojonych z autoklawizowanego betonu komórkowego PN-EN 12602 [4]. Obydwie normy identycznie formułują warunek nośno- 
ści ściskanych krzyżulców betonowych. Różnica występuje w określaniu nośności zbrojenia na ścinanie $w$ postaci strzemion. Nośności na ścinanie odcinków przypodporowych $V_{R}$ określono jako minimum z nośności krzyżulców ściskanych $V_{R 2, \text { cal }}$ i rozciąganych strzemion $V_{R 3 \text {,cal }} z$ zależności (3a) i (3b) wg EC-2 [5].

$$
\begin{aligned}
& \mathrm{V}_{\mathrm{R}, \text { test }}\left(\operatorname{ctg}\left(\Theta_{\text {test }}\right)\right)=\min \left(\mathrm{V}_{\mathrm{R} 2 \text {,est }}, \mathrm{V}_{\mathrm{R} 3 \text {,est }}\right) \\
& \mathrm{V}_{\mathrm{R}, \mathrm{cal}}\left(\operatorname{ctg} \Theta_{\text {cal }}\right)=\min \left(\mathrm{V}_{\mathrm{R} 2, \mathrm{cal}}, \mathrm{V}_{\mathrm{R} 3 \text {,cal }}\right)
\end{aligned}
$$

Wyniki badań zestawiono także z nośnością ścinanego zbrojenia w strefie podporowej $\mathrm{V}_{\mathrm{R} 3}$ wg zaleceń normy [4]. Do porównania obliczono również nośność na ścinanie odcinka zbrojonego strzemionami $Q_{\text {sb }}$ wg PN-84/B-03264 [6]. Wyniki obliczeń przedstawiono $\mathrm{w}$ tabeli 1 ., a w tabeli 2. porównano uzyskane wyniki badań i obliczeń.

Podane $\mathrm{w}$ tabeli 2. wartości sił niszczących $\mathrm{V}_{\mathrm{u} \text {,est }}$ uzyskane $\mathrm{w}$ badaniach uwzględniały ciężar własny belek oraz ciężar własny stalowego osprzętu. W metodach kratownicowych [4], [5], przy $\Theta_{\text {test }}$ i $\Theta_{\text {cal }}$ (za wyjątkiem elementu A3) najmniejszą siłę uzyskiwano z warunku nośności rozciąganych krzyżulców stalowych - strzemion.

Tabela 1. Wartości obliczonych poprzecznych sił niszczących

\begin{tabular}{|c|c|c|c|c|c|c|c|c|c|}
\hline \multirow{2}{*}{ Seria } & \multirow{2}{*}{ Element } & \multirow{2}{*}{$\operatorname{ctg}\left(\Theta_{\text {test }}\right)$} & \multirow{2}{*}{$\operatorname{ctg} \Theta_{\text {cal }}$} & \multicolumn{2}{|c|}{$\mathrm{V}_{\mathrm{R} 2 \text {,cal }}[\mathrm{kN}]$} & \multicolumn{2}{|c|}{$\mathrm{V}_{\mathrm{R} 3, \mathrm{cal}}[\mathrm{kN}]$} & \multirow{2}{*}{$\begin{array}{l}\mathrm{V}_{\mathrm{R} 3} \\
{[\mathrm{kN}]}\end{array}$} & \multirow{2}{*}{$\begin{array}{r}\mathrm{Q}_{\mathrm{sb}} \\
{[\mathrm{kN}]}\end{array}$} \\
\hline & & & & $\operatorname{ctg}\left(\Theta_{\text {test }}\right)$ & $\operatorname{ctg} \Theta_{\text {cal }}$ & $\operatorname{ctg}\left(\Theta_{\text {test }}\right)$ & $\operatorname{ctg} \Theta_{\mathrm{cal}}$ & & \\
\hline \multirow{3}{*}{ A } & 1 & 0,87 & 1,56 & $39,9 * *$ & 36,6 & $20,3^{* *}$ & 36,6 & 14,8 & 32,7 \\
\hline & 2 & 0,93 & 1,56 & $40,2 * *$ & 36,6 & $21,8 * *$ & 36,6 & 14,8 & 32,7 \\
\hline & $3 *$ & $0,29 *$ & 1,56 & $21,3^{*}$ & 36,6 & $6,7 *$ & 36,6 & 14,8 & 32,7 \\
\hline \multirow{2}{*}{$\mathrm{C}$} & 1 & 0,87 & 0,85 & $39,9 * *$ & 39,7 & $40,7 * *$ & 39,7 & 20,8 & 53,7 \\
\hline & 2 & 0,97 & 0,85 & $40,2 * *$ & 39,7 & $45,2 * *$ & 39,7 & 20,8 & 53,7 \\
\hline $\mathrm{D}$ & 1 & 1,15 & 0,85 & 49,8 & 49,6 & 141,5 & 104,5 & 42,7 & 106,9 \\
\hline
\end{tabular}

Table 1. The values of calculated and ultimate shear forces

* - wartość pominięta, ze względu, na rzeczywiste pochylenie krzyżulca nie spełniającego wymogów normy [5] ** - hipotetyczne wartości siły ścinającej przyjęte do dalszej analizy przy pominięciu utraty nośności zakotwienia zbrojenia podłużnego

Tabela 2. Porównanie uzyskanych wyników badań i obliczeń

\begin{tabular}{|c|c|c|c|c|c|c|c|c|}
\hline \multirow[t]{2}{*}{ Seria } & \multirow[t]{2}{*}{ Element } & $\mathrm{V}_{\mathrm{u}, \text { test }}$ & $\begin{array}{c}\mathrm{V}_{\mathrm{R}, \text { test }}\left(\operatorname{ctg}\left(\Theta_{\text {test }}\right)\right) \\
\text { wg }(3 \mathrm{a}) \\
\end{array}$ & $\begin{array}{c}\mathrm{V}_{\mathrm{R}, \mathrm{cal}}\left(\mathrm{ctg} \Theta_{\text {cal }}\right) \\
\mathrm{wg}(3 \mathrm{~b})\end{array}$ & \multirow{2}{*}{$\frac{V_{u, t e s t}}{V_{R, \text { test }}}$} & \multirow{2}{*}{$\frac{V_{u, \text { test }}}{V_{R, \text { cal }}}$} & \multirow{2}{*}{$\frac{V_{u, \text { test }}}{V_{R, 3}}$} & \multirow{2}{*}{$\frac{V_{u, t e s t}}{Q_{s b}}$} \\
\hline & & \multicolumn{3}{|c|}{$[\mathrm{kN}]$} & & & & \\
\hline \multirow{3}{*}{ A } & 1 & 11,2 & 20,3 & 36,6 & 0,55 & 0,31 & 0,75 & 0,34 \\
\hline & 2 & 13,1 & 21,8 & 36,6 & 0,60 & 0,36 & 0,88 & 0,40 \\
\hline & 3 & 13,8 & $6,7 *$ & 36,6 & $2,06^{*}$ & 0,38 & 0,93 & 0,42 \\
\hline \multirow{2}{*}{$\mathrm{C}$} & 1 & 14,5 & 39,9 & 39,7 & 0,36 & 0,37 & 0,70 & 0,27 \\
\hline & 2 & 13,5 & 40,2 & 39,7 & 0,34 & 0,34 & 0,65 & 0,25 \\
\hline $\mathrm{D}$ & 1 & 44,1 & 49,8 & 49,6 & 0,89 & 0,89 & 1,03 & 0,41 \\
\hline
\end{tabular}

Table 2. The comparison of tests and calculations results 
Obliczone wg metody kratownicowej nośności na ścinanie nadproży (przy $\Theta_{\text {test }}$ ) były poza nadprożem A3 większe o $11 \% \div 66 \%$ od wartości uzyskanej w badaniach. Przy ctg $\Theta_{\text {cal }}$, nośność na ścinanie wzrosła. W przypadku obliczeń przeprowadzonych wg [4] nośności na ścianie odcinków drugiego rodzaju zmalały, ale dalej były o $7 \% \div 25 \%$ większe od sił niszczących uzyskanych w badaniach a w elemencie D1 obliczona była mniejsza o 3\% od wartości empirycznej. Uzyskane wyniki, wykazały, w jakim stopniu przeszacowano nośności na ścinanie, zakładając kratownicowy model zniszczenia, uwzględniający poprawne zakotwienie zbrojenia rozciąganego. Największe przeszacowanie obliczeniowej nośności na ścinanie rzędu $59 \% \div 75 \%$ uzyskano stosując metodę obliczania nośności na ścinanie, przyjętą w PN-84/B-03264 [6]. Wykorzystującą z kolei, model z przekrojem zniszczenia, ale również zakładającą poprawne zakotwienie zbrojenia podłużnego.

Projektując ścinane elementy można zgodnie z normą [5], przyjąć $\operatorname{ctg} \Theta$ w zakresie $\langle 1-2,5\rangle$. W przypadku analizowanych nadproży wartość $\operatorname{ctg} \Theta>2$ nie było możliwe ze względu na długość odcinka ścinania biegnącego od podpory do punktu przyłożenia. W tabeli 3. przedstawiono wyniki obliczeń nośności w odniesieniu do wartości sił uzyskanych w badaniach przy granicznych wartościach $\operatorname{ctg} \Theta=1$ i $\operatorname{ctg} \Theta=2$.

Tabela 3. Wartości obliczonych poprzecznych sił niszczących

Table 3. The values of calculated ultimate shear forces

\begin{tabular}{|c|c|c|c|c|c|c|c|c|c|c|}
\hline \multirow[t]{2}{*}{ 氶 } & \multirow[t]{2}{*}{ 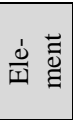 } & \multirow[t]{2}{*}{$\mathrm{V}_{\mathrm{u}, \mathrm{test}}$} & $\mathrm{V}_{\mathrm{R}, 2} \operatorname{ctg} \Theta$ & \multirow{2}{*}{$\begin{array}{l}\mathrm{V}_{\mathrm{R}, 3} \operatorname{ctg} \Theta \\
=1\end{array}$} & $\mathrm{~V}_{\mathrm{R}, 2} \mathrm{ctg} \Theta$ & $\mathrm{V}_{\mathrm{R}, 3} \operatorname{ctg} \Theta$ & $\frac{V_{u, \text { test }}}{V_{R, 2} \cot \Theta}$ & $\frac{V_{u, t e s t}}{V_{R, 3} \cot \Theta}$ & $\frac{V_{u, \text { test }}}{V_{R, 2} \cot \Theta}$ & $\frac{V_{u, t e s t}}{V_{R, 3} \cot \Theta}$ \\
\hline & & & $\operatorname{ctg} \Theta=1$ & & \multicolumn{2}{|c|}{$\operatorname{ctg} \Theta=2$} & \multicolumn{2}{|c|}{$\operatorname{ctg} \Theta=1$} & \multicolumn{2}{|c|}{$\operatorname{ctg} \Theta=2$} \\
\hline \multirow{3}{*}{ A } & 1 & 11,2 & 40,3 & 32,2 & 23,4 & 46,8 & 0,28 & 0,35 & 0,48 & 0,24 \\
\hline & 2 & 13,1 & 40,3 & 32,2 & 23,4 & 46,8 & 0,32 & 0,41 & 0,56 & 0,28 \\
\hline & 3 & 13,8 & 40,3 & 32,2 & 23,4 & 46,8 & 0,34 & 0,43 & 0,59 & 0,30 \\
\hline \multicolumn{7}{|r|}{ średnio: } & 0,31 & 0,40 & 0,54 & 0,27 \\
\hline \multirow{2}{*}{$\mathrm{C}$} & 1 & 14,5 & 40,3 & 32,2 & 46,8 & 93,6 & 0,36 & 0,45 & 0,31 & 0,15 \\
\hline & 2 & 13,5 & 40,3 & 32,2 & 46,8 & 93,6 & 0,34 & 0,42 & 0,29 & 0,14 \\
\hline \multicolumn{7}{|r|}{ średnio: } & $\mathbf{0 , 3 5}$ & 0,44 & $\mathbf{0 , 3 0}$ & 0,15 \\
\hline $\mathrm{D}$ & 1 & 44,1 & 50,2 & 40,2 & 123,0 & 245,9 & 0,88 & 1,10 & 0,36 & 0,18 \\
\hline
\end{tabular}

Nośność belek z ABK projektowana przy kącie pochylenia krzyżulców wynoszącym $\operatorname{ctg} \Theta=1 \mathrm{w}$ elementach serii A i C była średnio o 65\% - 69\% większa od wartości eksperymentalnej i decydujące znaczenie miała nośność ściskanego krzyżulca betonowego $V_{R 2}$. Zwiększenie długości odcinka ścinania i przyjęcie $\operatorname{ctg} \Theta=2$ odwróciło tendencję, o nośności decydowała wówczas nośność zbrojenia $V_{R 3}$, ale przeszacowanie nośności wynosiło od $73 \%-85 \%$. W belce o największym podłużnym zbrojeniu, w której nie wystąpiła utrata nośności zakotwienia podłużnego zbrojenia, otrzymano najlepszą zgodność wyników z obliczeniami, przy największym pochyleniu krzyżulców ctg $\Theta=1$. Nośność z uwagi na ściskane krzyżulce była o 12\% mniejsza od wartości eksperymentalnej. Przy 
największym pochyleniu krzyżulców i $\operatorname{ctg} \Theta=2$ przeszacowanie nośności było największe. Powyższe wyniki wskazują, że w elementach serii A i C stosując obowiązujące algorytmy projektowania uzyskuje się znaczne i niebezpieczne przeszacowanie nośności na ścinanie. Wynika to oczywiście z braku pełnego wykorzystania poprzecznego zbrojenia spowodowanego nie w pełni wykształtowaną kratownicą w strefie przypodporowej.

W związku z tym sprawdzenie nośności na ścinanie, w elementach tego typu powinno być każdorazowo poprzedzone sprawdzeniem nośności zakotwienia zbrojenia podłużnego, nawet przy spełnieniu warunków konstrukcyjnych. Konieczność stosowania powłok ochronnych zbrojenia powoduje, że w belkach z ABK, właściwe zakotwienie podłużnego zbrojenia uzyskuje się stosując poprzeczne zbrojenie (strzemiona).

Zgodnie z wytycznymi normy [4] przeprowadzono weryfikację obliczeniowej nośności zakotwienia zbrojenia podłużnego pomijając przyczepność zbrojenia do betonu komórkowego, ale uwzględniając poprzeczne zbrojenie w postaci strzemion. Na podstawie obrazów zniszczenia nadproży w każdej z serii przyjęto liczbę strzemion kotwiących $\mathrm{n}_{\mathrm{t}}$. Następnie wyznaczono nośność zakotwienia poprzecznych prętów kotwiących $\mathrm{F}_{\mathrm{RA}}$, a na tej podstawie obliczono odpowiada-

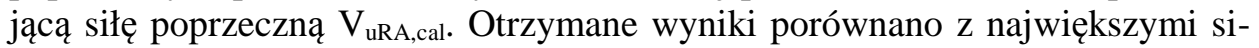
łami poprzecznymi $\mathrm{V}_{\mathrm{u} \text {,test }}$ uzyskanymi w belkach w każdej serii. Wyniki obliczeń zestawiono w tabeli 4.

Tabela 4. Porównanie nośność elementów na ścinanie wyznaczonych $\mathrm{z}$ warunku zakotwienia zbrojenia podłużnego z wynikami badań

Table 4. The comparison of the shear capacity determined from the anchorage condition of the longitudinal reinforcement with the test results

\begin{tabular}{|c|c|c|c|c|c|c|}
\hline Seria & Element & $\mathrm{n}_{\mathrm{t}}$ & $\begin{array}{c}\mathrm{F}_{\mathrm{RA}} \\
{[\mathrm{kN}]}\end{array}$ & $\begin{array}{c}\mathrm{V}_{\mathrm{uRA}, \mathrm{cal}} \\
{[\mathrm{kN}]}\end{array}$ & $\begin{array}{c}\mathrm{V}_{\mathrm{u}, \text { test }} \\
{[\mathrm{kN}]}\end{array}$ & $\frac{V_{u R A, c a l}}{V_{u, \text { test }}}$ \\
\hline $\mathrm{A}$ & 3 & 3 & 16,5 & 7,7 & 13,8 & 0,56 \\
\hline $\mathrm{C}$ & 1 & 6 & 33,5 & 15,7 & 14,5 & 1,08 \\
\hline $\mathrm{D}$ & 1 & 4 & 97,3 & 44,2 & 44,1 & 1,00 \\
\hline
\end{tabular}

Najmniejsze różnice pomiędzy obliczeniową siłą poprzeczną wynikającą z nośności zakotwienia a rzeczywistą siłą poprzeczną uzyskano w nadprożach D1 i C1. W belce z D1 siła poprzeczna wynikająca z nośności zakotwienia odpowiadała niszczącej sile uzyskanej w badaniach. $\mathrm{Z}$ kolei w belce $\mathrm{C} 1$ siła $\mathrm{V}_{\text {uRA,cal }}$ była o 8\% większa od siły niszczącej uzyskanej w eksperymentach. Najbezpieczniejsze oszacowanie nośności belki otrzymano w nadprożu A3, w której siła poprzeczna wynikająca z nośności zakotwienia była o $44 \%$ mniejsza od siły niszczącej $\mathrm{V}_{\mathrm{u}, \text { test. }}$. 
Uzyskane rezultaty sugerują, że w belkach z ABK obliczanych, jako elementy swobodnie podparte bez współpracy z murem (i docisku do dolnej i górnej powierzchni belki) sprawdzenie nośności na ścinanie według zaleceń normowych, nie jest warunkiem wystarczającym i może prowadzić do niebezpiecznych rezultatów. Podobnie niebezpieczne wydaje się, przyjęcie, że zakotwienie zbrojenia podłużnego, spełniające wymogi normowe, jest warunkiem wystarczającym pozwalającym zastosować kratownicową metodę obliczeń. Obliczanie na ścinanie tego typu elementów (bez zakotwienia w postaci haków lub pętli), powinno być każdorazowo poprzedzone sprawdzeniem nośności zakotwienia z uwzględnieniem wszystkich poprzecznych prętów występujących w strefie oparcia.

\section{Podsumowanie i wnioski}

Zniszczenie wszystkich badanych nadproży nastąpiło w strefach przypodporowych. Powstały ukośne zarysowania, które poprzedzały w wypadku elementów serii A i C utratę nośności zakotwienia zbrojenia podłużnego. Przy spełnieniu warunków zakotwienia zbrojenia podłużnego, sprawdzenia nośności można dokonywać stosując model kratownicowy. Obliczenia weryfikacyjne przeprowadzone według trzech metod wykazały, znaczne przeszacowania nośności w stosunku do uzyskanych wyników badań doświadczalnych. Najbardziej zbliżone rezultaty otrzymano stosując normę [4] dedykowaną elementom z ABK. Zgodnie z jej zaleceniami przy zastosowaniu pochylenia ściskanych krzyżulców $\operatorname{ctg} \Theta=1$ w belkach serii A i C uzyskano wyraźne przeszacowanie nośności, a najbardziej zbliżone wyniki obliczeń nośności na ścinanie otrzymano w wypadku belki serii D. Ze względu na sposób zniszczenia belek spowodowanego przez utratę przyczepności wykonano dodatkowe obliczenia sprawdzające polegające na wyznaczeniu siły poprzecznej na podstawie nośności zakotwienia. W tym wypadku obliczone siły poprzeczne były albo mniejsze (seria A) o 44\%, lub niewiele większe (seria C) o 8\%, a nawet równe (seria D) empirycznym siłom niszczącym.

Reasumując, w odróżnieniu od prawidłowo skonstruowanych żelbetowych elementów zginanych, w których kratownicowe modele sprawdzania nośności dają zazwyczaj bezpieczne rezultaty, w belkach z ABK można uzyskać wyniki niebezpieczne. Wynika to nie tylko z niewielkiej wytrzymałości betonu komórkowego na rozciąganie, ale także z ograniczenia naprężeń przyczepności spowodowanych zastosowaniem powłok ochronnych (mineralnych lub $\mathrm{z}$ tworzywa sztucznego). Nawet zastosowanie zgrzanych do podłużnego zbrojenia strzemion wywoływało utratę zakotwienia podłużnego zbrojenia, nie spełniając w tym wypadku roli poprzecznego zbrojenia kotwiącego. W belkach stanowiących przedmiot niniejszych badań, otrzymano bezpieczne rezultaty w zakresie nośności elementów wyznaczając poprzeczną siłę na podstawie nośności zakotwienia zbrojenia. Przy tak złożonym mechanizmie zniszczenia belek w strefach przypodporowych, polegającym na pierwotnym zarysowaniu ukośnym i wtórnym zniszczeniu zakotwienia warunkiem koniecznym i wystarczającym pozwalają- 
cym bezpiecznie oszacować nośność belki powinno być sprawdzeniem nośności zakotwienia przy jednoczesnym pominięciu naprężeń przyczepności (bez względu na poprawność długości zakotwienia prętów).

Autorzy badań wyrażaja szczególne podziękowania firmie Solbet sp. z o.o. za podjęcie wspótpracy z Katedra Konstrukcji Budowlanych oraz merytoryczna $i$ materialna pomoc przy realizacji badań konstrukcji murowych.

\section{Literatura}

[1] PN-EN 845-2:2013-10 Specyfikacja wyrobów dodatkowych do murów. Część 2: Nadproża.

[2] PN-EN 846-9:2002 Metody badań wyrobów dodatkowych do wznoszenia murów. Część 9: Określenia nośności na zginanie i ścinanie belek nadprożowych.

[3] PN-EN 1356:1999 Badanie właściwości użytkowych elementów zbrojonych z autoklawizowanego betonu komórkowego lub betonu lekkiego kruszywowego o otwartej strukturze przy zginaniu.

[4] PN-EN 12602+A1:2013-11 Prefabrykowane elementy zbrojone z autoklawizowanego betonu komórkowego.

[5] PN-EN 1992-1-1:2008/NA:2010 Eurokod 2: Projektowanie konstrukcji z betonu. Część 1-1: Reguły ogólne i reguły dla budynków.

[6] PN-84/B-03264 Konstrukcje betonowe, żelbetowe i sprężone. Obliczenia statyczne i projektowanie.

[7] Knauff M., Klempka K.: Algorytmy i wykresy do wymiarowania zbrojenia na ścinanie według Eurokodu 2. Inżynieria i Budownictwo Nr 2/98, s. 78-80.

[8] Mazur W. Drobiec L., Jasiński R.: Research of Light Concrete Precast Lintels. Procedia Engineering 161/2016, pp. 611-617.

[9] PN-EN 679:2008 Oznaczanie wytrzymałości na ściskanie autoklawizowanego betonu komórkowego.

[10] PN-EN ISO 6892:2010 Metale. Próba rozciągania. Część 1: Metoda badania w temperaturze pokojowej.

\section{CAPACITY OF THE ENDS OF PRECAST LINTELS MADE OF AUTOCLAVED AERATED CONCRETE}

\section{S u m m a r y}

The paper presents the experimental results and analytical calculations of capacity of the ends of lintels made of Autoclaved Aerated Concrete. Three series of elements with different dimensions of specimens cross-section and types of reinforcement were taken into consideration. Significant influence of the method of anchoring of the longitudinal bars on the bearing capacity of the beams has been shown.

Keywords: Autoclaved Aerated Concrete, precast lintels, shear capacity, anchorage

Przestano do redakcji: 26.05 .2017 r.

Przyjęto do druku: 01.06.2017 r. 